\title{
Is there a relationship between ethylene production of bananas ripened on the plant and the length of the fruit growth period prior to ripening onset?
}

Marc CHILlet ${ }^{a}$, Colette GALAS ${ }^{b}$, Rose-Marie Gomez ${ }^{b}$, Olivier HuberT ${ }^{a}$, Philippe JuLIANUs ${ }^{b}$, Didier MbÉGUIÉ-A-MbÉGUIÉa, Bernard FILS-LYCAON ${ }^{\text {b* }}$

a CIRAD, Station de Neufchâteau, Sainte-Marie, 97130 Capesterre Belle-Eau, Guadeloupe, France

b INRA-CRAG, URTPV, Domaine de Duclos, 97170 Petit-Bourg, Guadeloupe, France Bernard.Fils-Lycaon@ antilles.inra.fr
${ }^{*}$ Correspondence and reprints

Received 23 February 2004 Accepted 13 January 2005

Fruits, 2005, vol. 60, p. 83-89 (C) 2005 Cirad/EDP Sciences All rights reserved

DOI: $10.1051 /$ fruits:2005015

RESUMEN ESPAÑoL, p. 89
Is there a relationship between ethylene production of bananas ripened on the plant and the length of the fruit growth period prior to ripening onset?

Abstract - Introduction. A recent laboratory study demonstrated a negative correlation between the ethylene production of fruit during ripening and the length of their commercial life. The aim of our work was to determine whether there is a putative relationship between ethylene production of fruit during ripening and the length of the growth period before ripening. A positive answer would make this an important parameter for early selection in breeding programs. Materials and Methods. Four banana varieties representing a broad range of growth period lengths were studied. Ethylene biosynthesis was examined through ethylene production and content in free 1-aminocyclopropane-1-carboxylic acid (ACC)-the immediate precursor of the hormone-during fruit development and ripening. Fruit ripening was totally achieved on the plant. Results. Ethylene production started to be detected at the breaker stage. It peaked at the "fully dark-yellow-extremities included" stage for all varieties. Two varieties, i.e., Sowmuk and IDN 110, presented the highest production levels [(26 and 19) $\mu \mathrm{L}$ ethylene $\cdot \mathrm{h}^{-1} \cdot \mathrm{kg}^{-1}$ of fresh weight at peak, respectively). Galéo and Grande Naine had lower ethylene yields. The two most productive varieties also presented a drastic increase in free ACC at ripening onset. Conclusion. There is no relationship between ethylene production of bananas ripened on the plant and the length of the fruit growth period prior to ripening onset.

France / Musa (bananas) / fruits / developmental stages / ripening / ethylene production

\section{Y a-t'il une relation entre la production d'éthylène de bananes mûrissant sur le bananier et la longueur de la phase de croissance du fruit avant le début de sa maturation?}

Résumé - Introduction. Une étude récente menée en laboratoire a mis en évidence une corrélation négative entre la production d'éthylène des bananes pendant leur maturation et leur durée de vie commerciale. L'objectif de notre travail a été de savoir s'il existait une relation entre la production d'éthylène du fruit pendant la maturation et la durée de la période de croissance en vert, avant que la maturation ne commence. Une réponse positive serait importante pour une sélection précoce lors de programmes de création variétale. Matériel et méthodes. Quatre variétés présentant différentes durées de phase de croissance ont été étudiées. La biosynthèse d'éthylène a été suivie par la production d'éthylène et la teneur en acide 1-aminocyclopropane1-carboxylique (ACC), le précurseur immédiat de cette hormone, pendant le développement et la maturation du fruit. Les fruits ont totalement mûri sur le bananier. Résultats. La production d'éthylène a commencé à être détectée au stade de coloration tournant du fruit. Pour les quatre variétés étudiées, elle a été maximale au stade "complètement jaune soutenu, y compris les extrémités ". Deux variétés, Sowmuk et IDN 110, ont eu les niveaux de production d'éthylène les plus élevés [respectivement, des maxima de (26 et 19) $\mu \mathrm{L}$ d'éthylène $\cdot \mathrm{h}^{-1} \cdot \mathrm{kg}^{-1}$ de poids frais]. Les variétés Galéo et Grande Naine ont eu des productions plus faibles. Les deux variétés les plus productives en éthylène sont celles qui ont présenté une forte augmentation de leurs teneurs en ACC libre juste avant la maturation. Conclusion. Il n'y a pas de corrélation entre la production d'éthylène de bananes mûries sur le bananier et la longueur de la phase de croissance avant le début de la maturation.

France / Musa (bananes) / fruits / stade de développement / maturation / production d'éthylène 


\section{Introduction}

Ethylene is a plant growth regulator that has been shown to regulate numerous physiological processes in plants. Production of this gaseous hormone in the plant is normally low but greatly induced at certain stages of plant development such as seed germination, leaf and flower abscission, fruit ripening, or in response to a wide range of external stimuli including auxin treatment, wounding, anaerobiosis, drought, flooding or pathogen attacks [1-3]. Its biosynthetic pathway in higher plants is well established [4]:

Methionine $\rightarrow$ S-adenosyl methionine (SAM) $\rightarrow$ 1-aminocyclopropane-1-carboxylic acid (ACC) $\rightarrow$ ethylene

The two latter steps are catalyzed by ACC synthase and ACC oxidase, respectively.

Fruits have been classified as climacteric and non-climacteric on the basis of their respiration and ethylene production at the onset of ripening [5]. In climacteric fruit, in addition to the induction of some genes involved in biochemical changes that improve taste and flavor during ripening, ethylene enhances its own production by inducing ACC synthase and ACC oxidase genes [2, 6].

Banana (Musa spp.) is a typical climacteric fruit. Fruit development on banana plants is characterized by a growth step during which the fruit stays green and accumulates starch, followed by a quick ripening phase [7]. The length of the growth step before ripening can vary according to the cultivar, climatic conditions, particularly temperature, and agricultural practices such as bunch covering [8]. This step is routinely designated as the "Interval between Flowering and the first Yellow banana appearing in the bunch" (IFY) ${ }^{1}$. A recent laboratory study (unpublished results) carried out on 20 varieties ripened after exogenous ethylene treatment revealed that varieties with the highest ethylene production during ripening had the shortest commercial life (esti-

\footnotetext{
${ }^{1}$ IFY is defined in degree-days (dd) as the sum of average daily temperatures minus $14{ }^{\circ} \mathrm{C}$ [9]. Fourteen degrees Celsius has been established as the minimal temperature necessary for the growth of cv. Grande Naine.
}

mated by tear-off susceptibility), which is a major market drawback. The aim of our work was to determine whether there is a putative relationship between ethylene production of fruit during ripening and IFY length. A positive answer would make this an important parameter for early selection in breeding programs. To address this question, an experiment was carried out with three diploid banana varieties (AA) and the commercial triploid Cavendish (AAA) variety as experimental control, i.e., four varieties representative of a broad IFY range. Ethylene biosynthesis was examined through ethylene production and content in free ACC - the immediate precursor of the hormone - during fruit ripening. Fruit ripening was totally achieved on the plant so as to avoid potential misinterpretations linked to a putative effect of the harvesting date of green diploid fruit on the production of ripening ethylene after exogenous ethylene treatment. Measurements of fruit peel color and pulp firmness were used as markers of fruit ripening.

\section{Materials and methods}

\subsection{Studied varieties}

Four varieties were studied: Galéo (AA cv.), with a very long IFY (approximately 1680 degree-days); IDN 110 (AA cv.), with a long IFY (approximately $1600 \mathrm{dd}$ ); Grande Naine (AAA cv. Cavendish), with a medium IFY (approximately $1350 \mathrm{dd}$ ); and Sowmuk (AA cv.), with a short IFY (approximately $800 \mathrm{dd}$ ). These varieties were grown in a plot (50 plants per variety) at Cirad, Station of Neufchâteau, Guadeloupe (France), French West Indies. Plants were grown in standard conditions, but bunches were also wrapped in wire mesh to avoid rat attacks, wounding and early ripening.

\subsection{Fruit harvesting}

Three banana bunches were cut for each variety and each harvested stage. The median hand of each bunch was always the only hand used as a fruit source. The four bananas 
from the sides of the hand were discarded and the remaining bananas were analyzed individually (weight and peel color measurements). According to these parameters, 35 equivalent fruits were retained for further analysis for each variety. The weight measurements are not shown in the results.

Banana bunches were harvested according to a fruit age-based scale. Firstly, harvests of green fruits were made according to a time-based scale: $75 \%$ of IFY [stage 1] and IFY [stage 2]. Then, fruits were harvested according to a color-based scale of the median hand, modified from [10]: breaker [stage 3], green-yellow [stage 4], light-yellow - extremities excluded [stage 5], fully darkyellow - extremities included [stage 6], fully dark-yellow with numerous large brown patches [stage 7].

At each harvest, the color of each harvested fruit was measured. The mean $a^{*}$-value of a $L^{*} a^{*} b^{*}$ color model was calculated, and the six bananas with the value closest to the mean were retained for the ethylene production measurement. Remaining fruits were measured for firmness, and then cut into small pieces and immediately frozen in liquid nitrogen. After mixing this plant material, several batches were prepared and stored at $-80^{\circ} \mathrm{C}$. One batch of fruit material was finally freeze-dried for subsequent free ACC measurement.

\subsection{Color measurement}

Fruit peel color was measured as the $\mathrm{a}^{*}$-value in a $L^{*} a^{*} b^{*}$ color model with a Minolta CR 200 chromameter.

\subsection{Firmness measurement}

Firmness was measured as an indicator of fruit ripening. Pulp firmness was measured with a TA-XT2 penetrometer. It corresponded to the maximal force needed to penetrate into the pulp $(1 \mathrm{~cm})$.

\subsection{Ethylene production measurement}

Ethylene production was measured at constant room temperature $\left(23^{\circ} \mathrm{C}\right)$ by confining individual intact fruit in a gas-tight $2-\mathrm{L}$ jar according to the method described by Chambroy et al. [11].

\subsection{Free ACC measurement}

ACC was extracted by mixing $3 \mathrm{~g}$ of ground freeze-dried material with $7 \mathrm{~mL}$ of $70 \%$ ethanol in a 50-mL sterile Falcon tube. The mixture was warmed to $90{ }^{\circ} \mathrm{C}$ (closed tube) in a closed water bath for $45 \mathrm{~min}$ and then filtered through a cloth filter to remove debris. The sample was then evaporated at $100{ }^{\circ} \mathrm{C}$ (open tube) in an open water bath. Four $\mathrm{mL}$ distilled water, $1 \mathrm{~mL}$ 10\% PEG 8 000, and $50 \mu \mathrm{L} 2 \mathrm{~N} \mathrm{HCl}$ were added to the dry residue. The mixture was then vortexed for $1 \mathrm{~min}$ and centrifuged at room temperature and $1200 \mathrm{~g}$ for $10 \mathrm{~min}$. The supernatant was neutralized with $50 \mu \mathrm{L}$ of $2 \mathrm{~N} \mathrm{NaOH}$ and filtered through a cloth filter. The sample was used immediately or frozen for storage and further analysis. The amount of free ACC was measured according to the following method, modified from Lizada and Yang [12]. Three hundred $\mu \mathrm{L}$ distilled water, $100 \mu \mathrm{L} 80 \mathrm{mM} \mathrm{HgCl}_{2}$, and $500 \mu \mathrm{L}$ sample were poured into a $12-\mathrm{mL}$ vial. The reaction was started by adding $100 \mu \mathrm{L}$ of the $\mathrm{NaOH} /$ $\mathrm{NaOCl}$ mixture to the previous one. The $\mathrm{NaOH} / \mathrm{NaOCl}$ mixture included $3.3 \mathrm{~g}$ of $\mathrm{NaOH}$ dissolved in $3 \mathrm{~mL}$ distilled water and $11 \mathrm{~mL} 15^{\circ} \mathrm{NaOCl}$. The vial was immediately closed, vortexed for a few seconds, and maintained on ice for $2.5 \mathrm{~min}$. After a second vortexing, $250 \mu \mathrm{L}$ of gas was drawn out of the 12-mL vial through its septum with a syringe and injected into the GC. Ethylene was separated from other gases as for the ethylene production measurement.

\section{Results}

\subsection{Color}

The $a^{*}$-value was the most descriptive $L^{*} a^{*} b^{*}$ color model value to express changes in peel color. Changes in fruit peel $a^{*}$-values during fruit development (figure 1) were used to confirm the real place of our harvests on a color-based scale. Stage 3 was 


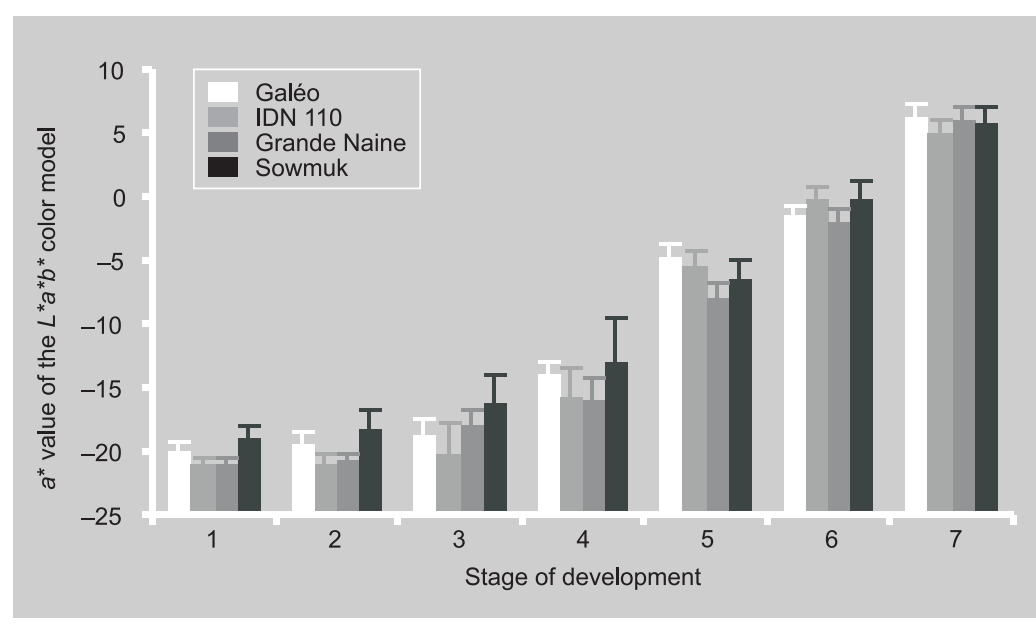

Figure 1.

Changes in banana peel $a^{*}$-values $\left(L^{*} a^{*} b^{*}\right.$ color model) during development (growth and ripening) of fruit on banana plants. The studied varieties are Galéo (AA diploid), IDN 110 (AA diploid), Grande Naine (AAA triploid) and Sowmuk (AA diploid). Measurements were obtained from 35 bananas.

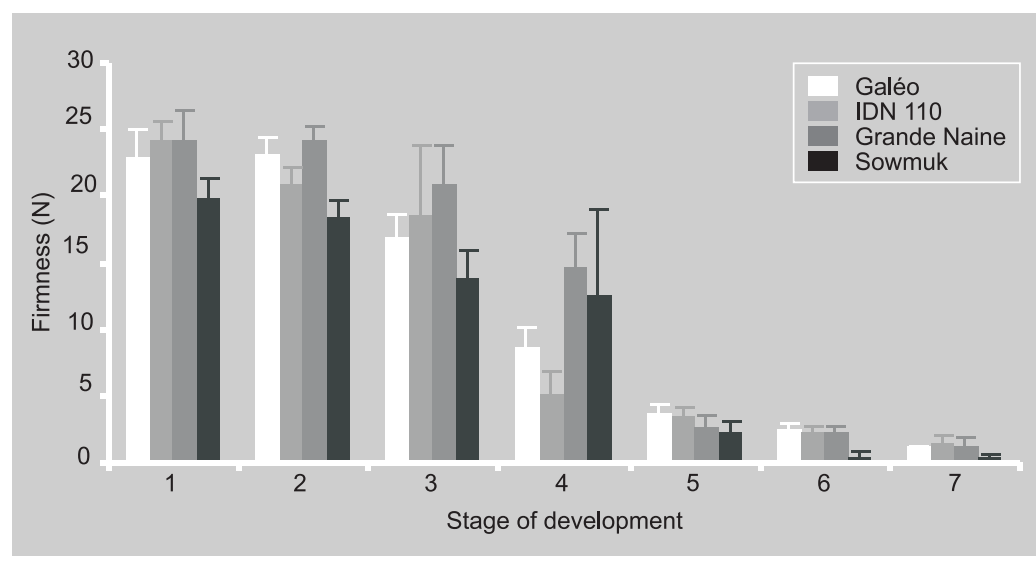

Figure 2.

Changes in pulp firmness during development (growth and ripening) of fruit on banana plants. The studied varieties are Galéo (AA diploid), IDN 110 (AA diploid), Grande Naine (AAA triploid) and Sowmuk (AA diploid). Measurements were obtained from 30 bananas. stage 6 (fully dark-yellow - extremities included). Note that, in our experiment, we did not try to establish a correlation between this color-based scale and a time-based one because of the difficulty of obtaining valid color measurements in the field.

\subsection{Firmness}

Firmness (figure 2) showed a classical variation pattern during ripening. The four studied varieties showed this pattern with minor differences in green fruit firmness levels. In all cases, residual firmness represented approximately $10 \%$ of the initial level at stage 5 (light-yellow - extremities excluded). These results confirm that ripening occurred normally.

\subsection{Ethylene production}

Ethylene production was undetectable for all varieties harvested at stages 1 and 2 (figure 3). We began to detect ethylene production at the breaker stage [stage 3]. It increased quickly at stage 4 for IDN 110 and seemed to peak at stage 6 for all varieties. Sowmuk and IDN 110 both presented the highest production levels [(26 and 19) $\mu \mathrm{L} \cdot \mathrm{h}^{-1} \cdot \mathrm{kg}^{-1}$ of fresh weight, respectively]. Galéo and Grande Naine had lower production.

\subsection{Free ACC content}

Galéo presented an almost constant level of free ACC, irrespective of the fruit developmental stage (figure 4). In contrast, the free ACC content of IDN 110 and Sowmuk increased slightly at stage 3 and was 2.4 and 5.9 times higher, respectively, for Sowmuk and IDN 110 at stage 4, where it peaked. It then steadily decreased until the overripe stage. The ACC content of Grande Naine was close to zero in the preclimacteric stages. It increased slowly from stage 3 to peak at a low level at stage 5 .

considered as the stage at which the value started to increase slightly by comparison with the approximately equal values obtained for stages 1 and 2. Stage 3 mainly showed a loss of green color intensity but the fruit peel still remained green. All varieties studied presented the same $a^{*}$-value variation pattern during ripening. An $a^{*}$ value close to 0 corresponded to fruit at

\section{Discussion and conclusion}

We studied the ethylene production of four banana varieties with different IFY lengths 
to determine whether there could be a putative relationship between ethylene production of fruit during ripening and the IFY length. Bananas were left to ripen on the plant and firmness measurements were used as an additional preliminary parameter to characterize ripening of the studied varieties.

Several studies on many species have demonstrated that fruit softening is the most ethylene-sensitive phase of the ripening process. Treatment of pears with low levels of exogenous ethylene or propylene induces softening but no other aspects of ripening [13], while, in melon, a highly positive correlation was noted between the rapid loss of firmness and the first detectable rise in internal ethylene [14]. Our results indicated that this was also the pattern in all of the banana varieties studied. All of them presented a typical softening pattern during ripening. Moreover, IDN 110, which showed a quick increase in ethylene production at stage 4, also presented a drastic decrease in firmness at this stage.

Galéo and Sowmuk are two so-called cooking varieties, and we thought that their firmness would be higher than that of dessert varieties at the ripe stage. Interestingly, their firmness decreased like the pattern noted in dessert varieties, and was even very low at the fully ripe stage for Sowmuk. This is an extra interesting point which raises the question as to what is actually responsible for the better sensorial firmness of these varieties, and as to the significance of the penetrometer firmness measurements.

Ethylene production levels could first be compared with data in the literature. Our results concerning Grande Naine are in accordance with those of other authors [1517]. However, as in other climacteric fruit, there was a broad range of ethylene production levels among the different studied varieties. Galéo presented higher production than Grande Naine, but the two most productive varieties were Sowmuk and IDN 110.

It is well known that the biosynthesis of ripening ethylene is regulated at the ACC synthase and ACC oxidase levels. Ethylene production is thus dependent at least on the availability of ACC, its precursor. Our ethylene results were corroborated by the free

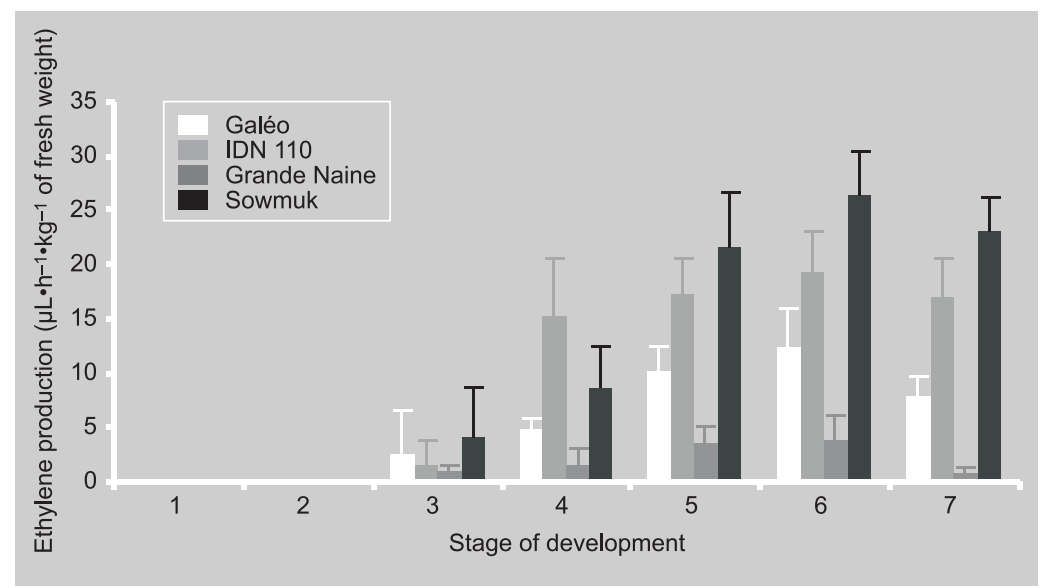

Figure 3.

Changes in ethylene production during the development (growth and ripening) of fruit on banana plants. The studied varieties are Galé (AA diploid), IDN 110 (AA diploid), Grande Naine (AAA triploid) and Sowmuk (AA diploid). Measurements were obtained from 6 bananas.

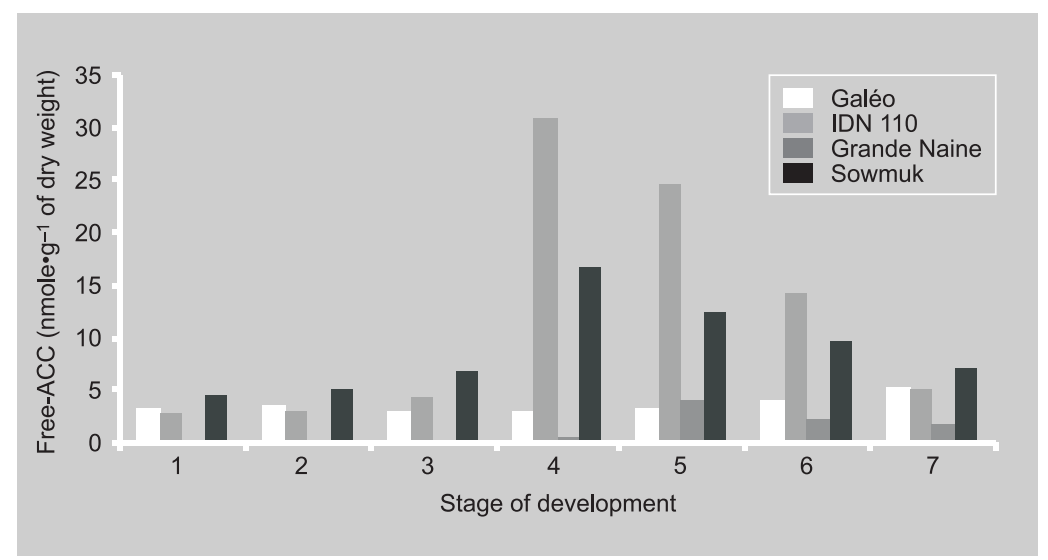

Figure 4.

Changes in free 1-aminocyclopropane-1-carboxylic acid (ACC) content of banana fruit pulp during development (growth and ripening) on banana plants. The studied varieties are Galéo (AA diploid), IDN 110 (AA diploid), Grande Naine (AAA tripolid) and Sowmuk (AA diploid). Measurements were performed once on a homogenized sample of plant material derived from 30 bananas.

ACC measurements since the two most productive varieties were those showing a drastic increase in free ACC content at the onset of ripening, and there is a good correlation $\left(r^{2}=0.80\right)$ between total free ACC measured during development and ripening [stage 1 to 7] and total ethylene production measured during ripening [stage 3 to 7] (figure 5). To conclude, our results (table I) also 


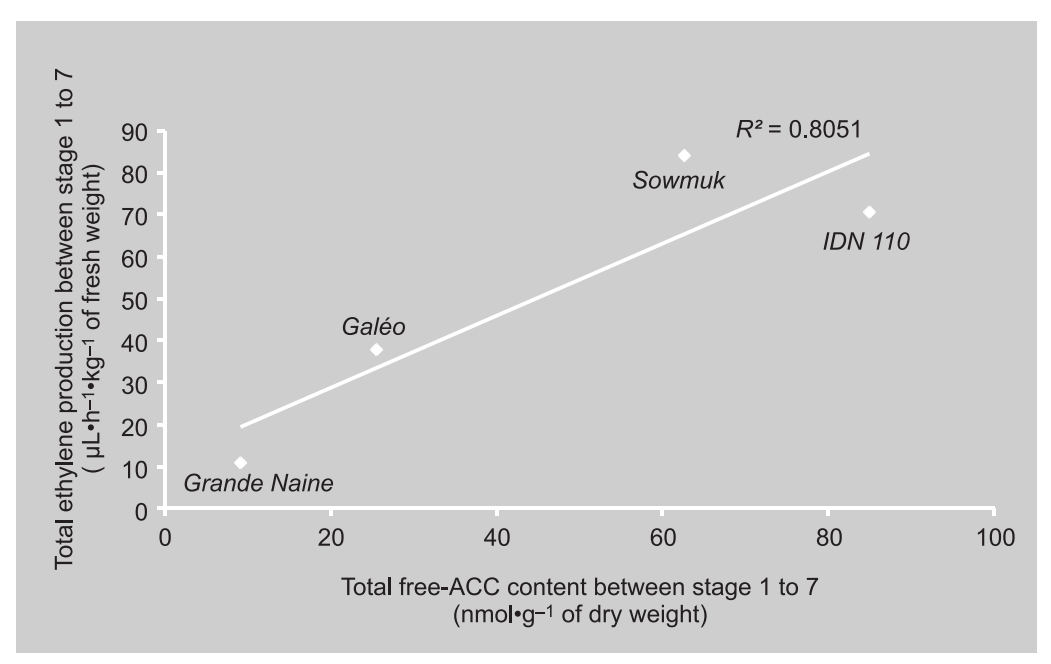

Figure 5.

Total ethylene production versus total free ACC measured between stages 1 and 7 of banana ripening for four studied varieties: Galéo (AA diploid), IDN 110 (AA diploid), Grande Naine (AAA tripolid) and Sowmuk (AA diploid).

\section{Table I.}

Length of the interval between flowering and the first yellow banana appearing in the bunch (IFY) and total ethylene production during ripening [stages 3 to 7] of banana fruit for Galéo, IDN 110, Grande Naine and Sowmuk banana varieties.

\begin{tabular}{lcc} 
Banana variety & $\begin{array}{c}\text { Length of IFY } \\
\text { (day-degree) }\end{array}$ & $\begin{array}{c}\text { Total ethylene production during ripening } \\
\left(\mu \mathrm{L} \cdot \mathrm{h}^{-1} \cdot \mathrm{kg}^{-1} \text { of fresh weight) }\right.\end{array}$ \\
\hline Galéo & 1680 & 37.62 \\
IDN 110 & 1600 & 70.54 \\
Grande Naine & 1350 & 10.75 \\
Sowmuk & 800 & 83.96
\end{tabular}

Stages 3 to 7 are part of a color-based scale for the banana median hand: breaker [stage 3], green-yellow [stage 4], light-yellow - extremities excluded [stage 5], fully dark-yellow - extremities included [stage 6], fully dark-yellow with numerous large brown patches [stage 7].

\section{Acknowledgements}

These results were extracted from a more global study supported by a special 1999 CIRAD/INRA joint funding grant. The authors are grateful to C. Jenny (CIRAD, Station de Neufchâteau, Guadeloupe, France, French West Indies) for providing plant material and for helpful discussions.

\section{References}

[1] Yang S.F., Hoffman N.E., Ethylene biosynthesis and its regulation in higher plants, Annu. Rev. Plant Physiol. 35 (1984) 155-189.

[2] Kende H., Ethylene biosynthesis, Annu. Rev. Plant Physiol. Plant Mol. Biol. 44 (1993) 283307.

[3] Yang S.F., Dong J.G., Recent progress in research of ethylene biosynthesis, Bot. Bull. Acad. Sci. 34 (1993) 89-101.

[4] Adams D.O., Yang S.F., Ethylene biosynthesis: identification of 1-aminocyclopropane1-carboxylic acid as an intermediate in the conversion of methionine to ethylene, Proc. Natl. Acad. Sci. USA 76 (1979) 170-174.

[5] Biale J.B., Young R.E., Respiration and ripening in fruits: retrospect and prospect, in: Friend J., Rhodes M.J.C. (Eds.), Recent advances in the biochemistry of fruits and vegetables, Acad. Press, London, 1981, pp. 1-39.

[6] Abeles F.B., Ethylene in plant biology, Acad. Press, New York, USA, 1973.

[7] Seymour G.B., Banana, in: Seymour G.B., Taylor J.E., Tucker G.A. (Eds), Biochemistry of fruit ripening, Chapman and Hall, London, UK, 1993, pp. 83-106.

[8] Mouen Bedimo J., Jullien A., Chillet M., de Lapeyre de Bellaire L., Influence de la date de la pose de la gaine sur le niveau de contamination des bananes par Colletotrichum musae, ainsi que sur la croissance du régime, Fruits 58 (2003) 3-13.

clearly demonstrated that there was no relationship between ethylene production of bananas ripened on the plant and the length of the fruit growth period before ripening onset $\left(r^{2}=0.20\right)$. The growth rate therefore cannot be used as a selection parameter for the evaluation of breeding products.
[9] Ganry J., Calcul des "sommes de vitesse de développement" et des températures moyennes journalières à partir du minimum et du maximum journaliers de la température, sous climat tropical et équatorial, Fruits 33 (1978) 221-236. 
[10] Anonyme, La maturation artificielle des bananes, Fruits d'Outre-Mer 4 (1949) 51-62.

[11] Chambroy Y., Souty M., Audergon J.M., Jacquemin G., Gomez, R.M., Researches on the suitability of modified atmosphere packaging for shelf-life and quality improvement of apricot fruit, Acta Hortic. 384 (1995) 633638.

[12] Lizada M., Yang S.F., A simple and sensitive assay for 1-aminocyclopropane-1-carboxylic acid, Anal. Biochem. 100 (1979) 140-145.

[13] Gerasopoulos D., Richardson D.G., Effects of exogenous propylene and fruit calcium on ripening of non-chilled and chilled Anjou pears, Postharvest Biol. Tec. 8 (1996) 111 120.

[14] Rose J.K.C., Hadfield K.A., Labavitch J.M., Bennett A.B., Temporal sequence of cell wall disassembly in rapidly ripening melon fruit, Plant Physiol. 117 (1998) 345-361.

[15] Dominguez E., Vendrell M., Ethylene biosynthesis in banana fruit: evolution of EFE activity and ACC levels in peel and pulp during ripening, J. Hortic. Sci. 68 (1993) 63-70.

[16] Medina-Suarez R., Manning K., Fletcher J., Aked J., Bird, C.R., Seymour G.B., Gene expression in the pulp of ripening bananas. Two-dimensional sodium dodecyl sulfatepolyacrylamide gel electrophoresis of in vitro translation products and cDNA cloning of 25 different ripening-related mRNAs, Plant Physiol. 115 (1997) 453-461.

[17] Liu X., Shiomi S., Nakatsuka A., Kubo Y., Nakumara R., Inaba A., Characterization of ethylene biosynthesis associated with ripening in banana fruit, Plant Physiol. 121 (1999) 1257-1266.

\section{¿Existe una relación entre la producción de etileno en plátanos que maduran sobre el plátano y la longitud de la fase de crecimiento del fruto antes del comienzo de su maduración?}

Resumen - Introducción. Un estudio reciente realizado en laboratorio puso de manifiesto una correlación negativa entre la producción de etileno en plátanos durante su maduración y la duración de su vida comercial. El objetivo de nuestro trabajo consistió en saber si existía una relación entre la producción de etileno del fruto durante la maduración y la duración del período de crecimiento verde, antes del comienzo de la maduración. Una respuesta positiva sería importante para una selección precoz durante los programas de creación de variedades. Material y métodos. Se estudiaron cuatro variedades que presentaban distintas duraciones de fase de crecimiento. A la biosíntesis de etileno le siguió la producción de etileno y el contenido en ácido 1-aminocyclopropano-1-carboxílico (ACC), el precursor inmediato de esta hormona, durante el desarrollo y la maduración del fruto. Los frutos maduraron completamente sobre el plátano. Resultados. La producción de etileno comenzó a detectarse durante la fase de coloración del fruto. Para las cuatro variedades estudiadas, ésta alcanzó su nivel máximo durante la fase "enteramente amarilla constante, incluidas las extremidades". Dos variedades, Sowmuk e IDN 110, tuvieron los niveles de producción de etileno más elevados [respectivamente con máximos de $\left(26\right.$ y 19) $\mu \mathrm{L}$ de etileno ${ }^{-1} \cdot \mathrm{kg}^{-1}$ del peso en fresco]. Las variedades Galéo y Grande Naine tuvieron producciones menores. Las dos variedades más productivas en etileno son las que presentaron un fuerte aumento de su contenido en ACC libre justo antes de la maduración. Conclusión. No hay correlación entre la producción de etileno en plátanos que maduran sobre el plátano y la longitud de la fase de crecimiento antes del comienzo de la maduración.

Francia / Musa (bananos) / frutas / etapas de desarrollo / maduración / producción de etileno 